\title{
Sites of Commodification and Exploitation in Mahasweta Devi's Breasts Stories
}

\author{
Mary Louisa Cappelli, JD, PhD \\ Independent Scholar, former Lecturer Emerson College.
}

\begin{abstract}
Mahasweta Devi's literary sexual reportage in Breast Stories documents how women's tortured bodies become the historical battleground of deeper socio-economic and political issues, their reproductive systems a discursive site for the examination of insurrection, resistance, and decolonization. In this analysis, I probe the socio-economic and cultural signification and commercialization of the breast in order to examine how women often employ them in their bare life struggles to combat poverty and starvation.
\end{abstract}

Key words: Mahasweta Devi, adivasis, survival politics, reproductive justice, breasts

\section{Discussion}

Bengali writer and social advocate, Mahasweta Devi, dedicated her life to supporting India's marginalized peoples and adivasi communities in an effort to bring them into political and historical memory. Mahasweta Devi's cultural production in Breast Stories provides a localized ethnographic space to examine and interrogate the plethora of layers of traditional and capitalist patriarchal forces that violently collude to undermine, deplete and ultimately collapse women's reproductive systems and well-being.

In "Breast-giver," often read as a parable about the decolonization of India, Mahasweta Devi "expands the thematics of the woman's political body" (Spivak, 2006, p. 355). Devi (1992) places her mother-goddess Jashoda as both metaphor for India as "mother for hire" in addition to documentary reportage of the oppressed mother and her lived experiences (p. 77). Questioning the sanctity of motherhood, Devi claims that she positions the subaltern wet nurse Jashoda to the body politic India who has been sucked dry of its fluids and resources by the nation-state India acting as a surrogate to the Global North. "Like the protagonist, India is a mother-by-hire" (Spivak, 2008, p.107). In so doing, she posits that if "scientific help comes too late, she will die of a consuming cancer" of globalized homogeneity (p. 78). The problem with a metaphorical reading of Jashoda as mother India is that it precludes the specific gendered experiences of sexual exploitation and oppression faced by subaltern women. Spivak (2008) points out that "When the woman's bodies is used only as a metaphor for a nation (or anything else) feminists correctly object to the effacement of the materiality of that body" and so distances "ourselves from the identity of the Woman with the female copulative and reproductive body" (p. 125). The breasts not only take on a historically coded meaning for the trauma of rape and exploitation of mother country India and resources, but also a personal meaning resistant to metaphor and symbolization. Similar to Devi's strong protagonists in "Draupadi," "Dhowli," and "The Hunt," women are driven by their battle for reproductive rights and by their bare life struggle to survive

(c) AesthetixMS 2016. This Open Access article is published under a Creative Commons Attribution Non-Commercial 4.0 International License (http://creativecommons.org/licenses/by-nc/4.o/), which permits non-commercial re-use, distribution, and reproduction in any medium, provided the original work is properly cited. For citation use the DOI. For commercial re-use, please contact aesthetixms@gmail.com. 
(Spivak, 2006, p. 355). How will they feed themselves? How will they feed their children? Jashoda uses the only means available to her-her breasts.

Devi positions the personal story of Jashoda working as a wet nurse so that elite Indian women can "can keep their figures" and "wear blouses and bras of European cut" to show off their perky breasts to their husbands while still serving as sexual playthings and mothers for their husband's desires (p. 107). Women's ability to "say no," is excluded from this domestic exchange. Jashoda's breasts become an exploited domestic site for the social reproduction of surplus exchange value, her milk a commodity appropriated by the westernized Indian elite who want their wives "to breed yearly," while keeping their bodies (Devi, p. 49). As "cow-mother," Jashoda's breasts are reified as "cheap labour" to the hungry mouths she is employed to nurse, her breasts transforming into "the alienated means of production, the part-object, the distinguishing organ of the female as mother" (Spivak, 2006, p. 368). In a "profundity" of a song, it is questioned: "Is a Mother so cheaply made? / Not just by dropping a babe?" (Devi, p. 50)

In this reproductive economy, Jashoda, gestates, lactates and produces the milk commodity to support her family unit. As Spivak (2008) points out, "By the logic of the production of value they are both means of production. By the logic of sexual production he is her means of production (though not owned by her as the field-beast or the beast of burden is the slave's" (p. 111-112). In this reportage, Devi substantiates how women's reproductive systems and reproductive affective labour is a strategic economic force at play in the marketplace even though Marx omitted "sexual reproduction" when addressing "social reproduction or reproduction of labour-power" (Spivak, "2008, p. 112). Jashoda's actions to become a "professional mother" and take "motherhood as her profession" enable her to feed her husband and children. Jashoda's production of milk is sexually produced through her reproductive system as a form of sexual reproductive energy.

Ann Ferguson (1989) refers to this as a form of sex/affective production, which includes "sexuality, nurturance of children whose satisfaction is just as basic to the functioning of society as is the satisfaction of the material needs of hunger and physical security" (p. 83). In the exchange of milk for compensation, Jashoda enters into unequal contractual relations reinforcing a social hierarchical interdependence in the exchange in which "human beings rather than material products and services" are produced (Ferguson, p. 83). Devi makes it quite clear, that Jashoda's sex/affective production is driven by a patriarchal system of domination and female subordination, where, yet again, women's reproductive systems are at the sexual and affective service of their male counterparts. Here we see how as Ann Ferguson posits: "The production of things and the production of people interpenetrate" in which Jashoda moves into an area of sex/affective production outside patriarchal control (qtd. in Spivak, 2006, p. 177). Jashoda's overworked body produces as both mother and working wet-nurse, confirming that she will supply more milk-product than she will be compensated for in this arrangement. Jashoda's mammary glands transfigure into "Cow of Fulfillment," and a vulnerable site of marketplace supply and demand (Devi, p. 48). Spivak (2008) posits:

That sphere is the site of the production of value, not things. As I have mentioned earlier, it is the body's susceptibility to the production of value which makes it vulnerable to idealization and therefore to insertion into the economic. This is the ground of the labour theory of value. It is here that the story of the emergency of value from Jashoda's labour power infiltrates Marxism and questions its gender-specific presuppositions. (p. 117)

In the end, Jashoda's breasts, which breast fed 20 of her own children and 50 others can no longer deliver to the demands of her hungry consumers. Jashoda's breast milk has dried up and she has lost her only means of production, her "left tit" "flaming red" "like a stone pushing inside" (Devi, 
p. 62). In the examination of Jashoda's strategy of survival-the implementation of her reproductive capacity as a mother is the act of motherhood itself. The narrator ponders that motherhood is an "addition" that doesn't seize "even when the milk is dry" (Devi, p. 6o). The narrator charges culpability to Jashoda herself for using her reproductive systems to save her family from starvation. "Jashoda's good fortune was her ability to bear children. All this misfortune happened to her as soon as that vanished" (Devi, p. 59). After Jashoda's "usefulness ended," she is discarded and throws herself at the mercy of the lion-seated, "her ageing, milkless, capacious breasts" afflicted from too much exploitation as suggested by the doctor (Devi, p. 57).

Jashoda rightfully questions why her "breasts betrayed her in the end" (Devi, p. 66). She had given all she knew how to give-the milk of her motherhood and must come to the realization that, "if you suckle you're a mother, all lies!" (Devi, p. 66). Although Spivak cautions against finding "precise answers" in theorizing the women's body, Devi's plot elements provide a convincing proposition for not only how the cancer of capital production spreads "at the expense of the human host," but how patriarchy colludes in this exploitative process (Devi, p. 73). "The sores on her breasts kept mocking her with a hundred mouths, a hundred eyes," wounds of capitalist patriarchy (Devi, p. 66). Here, Devi suggests the exploitive paradoxicality of the subaltern mother position, which serves as a dialectical host between patriarchal "indigenous and imperialist systems of domination" (Devi, p. 95). The violence of these hegemonic influences un-wombs the traditional mothering site of reproduction in the interest of capital production and imperial discourse in a world in a world even patriarchal science can't offer any way out. Devi is correct in her observation: "One patient's cancer means the patient's death and the defeat of science, and of course of the doctor" (Devi, pgs. 70-71).

Ultimately, Jashoda must meet her death alone, abandoned by all those in the community whom she suckled from her own children to the doctor and the untouchables. As Jashoda- "the mythic mother of Krishna and in that sense the suckler of the world"-she dies abandoned, her breasts rotting with putrescent cancer (Devi, p. 73).

In Behind the Bodice (Choli ke Picche) Devi recognizes that "Cultural invasion is much more dangerous than cultural revolution" (Devi, p. 136). In this short story, Devi juxtaposes transnational silicon occupied breasts with the natural breasts of India when protagonist Upin becomes obsessed with Gangor's breasts after photographing Gangor breast-feeding her baby. Devi explores how natural aboriginal breasts became an object of study and fetish fascination by media and anthropologists. In this narrative, protagonist Upin has been influenced by Bombay's cultural media and is later crushed by the Enlightenment train of progress while pondering Gangor's silicon-free mammal projections. Western influences metamorphosized the breast into a recreational preoccupation. Upin now fears that the natural uncorrupted breast is endangered by the exploitation of capital hegemonic forces; however, it is not only the infiltration of silicon that endangers the breast, but the objectification and the photographic capturing of its natural state for commercial purposes. The superficial obsession of the breast obfuscates more serious issues of crop failure, water scarcity and food security-an implied gang rape of the earth. This is not something that Upin's camera wanted and or focused to shoot and see. Upin's natural breast preoccupation complicates and interrogates external forces and dominant interrupting narratives that undermine, displace, and/or alter traditional domestic structures and familial cohesion. According to Devi, "There is no non-issue behind the bodice, there is a rape of the people behind it" (Devi, p. 155).

"Behind the Bodice" unfolds the tragedy at the global intersection of hegemonic influences emanating from Western media when photojournalist, Upin travels to Purulia to photograph 
tribal exploitation. Upin Puri snaps a shot of the breast-feeding young mother, Gangor, who "works on a piece-wage basis in the kilns for light bricks and tiles" (Devi, p. 141). Upin's frozen image exposes not only the Western gaze of the exotic natural woman's sexuality, but media construction of the breast as a commercial site of patriarchal fetishization and fascination. Devi probes the complex layers of socio-economic and cultural signification of the breast and how it has been commercialized into an object of gaze in India with England's exportation of the blouse as an article of moral cover-up. Devi attributes this moral cover up to an "anthropologist" who "went to Dandakaranaya forest after Independence," felt "shame" and asked the naked breasted women to "wear blouses" to cover up (Devi, p. 142).

Within this layering of patriarchal interests, Devi juxtaposes the anthropologist who lost his mind, the commercial introduction of the blouse, and Upin's fascination with Gangor's natural breasts and subsequent commodification of the breasts. It is important to note that Gangor "did not object" to the taking of the photo, but instead "put out her hand for money. "Snap a photo so give me cash!" she tells Upin (Devi, p. 141). Gangor's request for money subverts patriarchal relations in which women must assume a passive role of objectification. Instead, Gangor actively seeks compensation.

Ujan's lack of "cultural sensitivity" of "semi-famine conditions," is shocked by Gangor's response of remuneration; yet, Devi is quick to insert into this narrative frame the implicit "hidden agenda" in most all relief distribution programs (Devi, p. 142). In this media frenzy for the sexualized "exotic," Upin is able to sell his photos for exorbitant prices to media outlets such as National Pres and Lens Magazine. The photograph ends up stealing Gangor's reproductive livelihood by forcing her into a sexually coded spotlight of patriarchal attention, sexual fantasy, and community disgust, pushing Upin onto the borderland ledge of insanity, and ultimate death. Gangor's engagement in a quid pro quo of photograph for monetary compensation ends up being a social transgression of patriarchal monogamy. Gangor is charged and chastised for breaking this heterosexual bond of male ownership of her body parts.

Devi further shows how media's positioning of breasts in the forefront of news programming works to detract from more important discussions: "Crop failure-earthquake, everywhere clashes between so called terrorists and state power and therefore killings, the beheading of a young man and women in Haryana for the crime of marrying out of cast[e]..." (Devi, p. 134). Once again, Gangor's breasts divert the public away from more important issues of patriarchal capitalism's cruelty to women's conditions in which both females in this text have been equally burdened by sexual objectification. Whereas Gangor's “breasts are natural not manufactured," Upin's wife Shital's breasts are an enhanced liquid silicon fabrication of male fetishization -a fabrication that no longer captures Upin's sexual imagination (Devi, p. 152). Gangor's "statuesque" natural projections preoccupy Upin, and Devi rigorously interrogates this preoccupation. Behind his fiercely independent Himalayan climbing wife's "choli is a silicone chest" that "remain(s) aggressive forever" "like plastic flowers" (Devi, p. 147). Devi positions Shital as a hybridized fragment of cultural exchange that abdicates her role as "natural Indian woman" to become a commercial hybridization of both East and West, neither the one, nor the other, but "something else besides" in discourse that "intercut(s) across social sites and disciplines" (Bhabba, p. 92). Shital's Western-breasted otherness no longer fascinates Upin. "Why Gangor and her natural, most complex sweat glands or bosom had turned Upin's head he didn't know” (Devi, p. 147). Upin feels "that Gangor and her chest were endangered" from the forces that usurped Shital's breasts, the same forces from which he makes his living-patriarchal capitalism. It is perhaps this 
complicity in the exploitation, violence, and endangerment of female's reproductive systems that ultimately drives Upin insane.

Ultimately, Upin's breast pictures disseminate to Jharoa and come to the lustful attention of the police, Gangor's breasts taking on a power of their own. According to the caretaker, "the Gangors of this world don't come to die, Sir, they come to kill" (Devi, p. 149). The powerful mammary magnetism tempting "everyone to sin against God" including the police who eventually gang rape her (Devi, p. 150). Refusing yet again to be victimized by patriarchy, Gangor files a police report "and that's how all was lost" (Devi, p. 154). Abandoned by society, Gangor, like many of Devi's other females, must now earn a living as a prostitute-a result of Upin's initial commodification. In the end, Gangor's breasts are not breasts at all, but "Two dry scars, wrinkled skin, quite flat. The two raging volcanic craters spew liquid lava at Upin-gang rape...biting and tearing gang rape... police... a court case... again a gang rape in lock $\mathrm{u}[\mathrm{p}]$..." (Devi, p. 155). Devi indicts the entire phallocentric system in the violent mutilation and desecration against the Gangors of India, as "Women have to be careful in Shiva's world." "You're punished if you don't understand this" (Devi, p. 150).

Devi reveals in this patriarchal pantheon that there is "no non-issue behind the bodice, there is a rape of the people behind it" (Devi, p. 155). Realizing that his aspiration to save the endangered breasts is hopeless amidst the corrupt institutional layers of society, Upin is crushed by the weight of his own desire by the "wheels of the railway train midway between Jharoa and Seopura" (Devi, p. 137).

\section{Conclusion:}

Mahasweta Devi's Breast Stories provides important literary ethnographic discourse to explore the complicated socio-political relationships in which gender specific mistreatment and subjugation takes place. In "Breast-Giver" and "Behind the Bodice," we witness how mothers driven by struggles for food and water security strategically employ their breasts to reek out a subsistence living to provide enough food to feed their family. These local narratives of women's lived experiences offer documentation as to how patriarchal capitalist violence against women has propelled women to employ their reproductive systems as propertied sites of procreation and surplus value in order to save themselves and future generations from poverty and oppression. These works advance a discourse for "reading otherwise" in different geographic locations to examine the questions of power and patterns of resistance and female agency and what Anne McClintock calls the "politics of organization and strategy, which takes into account the myriad differences and loyalties that crisscross women's lives with conflicting passions" (p. 312). It is my hope that this essay will contribute to scholarship on how Western development and empowerment rhetoric for rural and indigenous women of the Global South interrupts and displaces traditional coding systems and subsistence livelihoods in the interest of capitalism. I contend that reproductive control and the gynocolonization of woman's bodies must be central to feminist social theories. Conclusively, Devi's indictment of patriarchy testifies to a need for reproductive justice and institutional change. 


\section{References}

Bhabba, Homi K. (1994). The Location of Culture. London: Routledge.

Devi, Mahasweta. (1992). Breast Stories. Trans. Gayatri Chakraborty Spivak, Kolkata: Seagull Books.

Ferguson, Ann. (1989). Blood at the Root: Motherhood, Sexuality and Male Dominance. London: Pandora Press.

Spivak, Gayatri Chakravorty. (2006). In Other Worlds: Essays In Cultural Politics. New York: Routledge.

.(2008). "A Literary Representation of the Subaltern: Mahasweta Devi's' 'Stanadayini'." Mahasweta Devi: An Anthology of Recent Criticism. Ed. Nivedita Sen and Nikhil Yadav. New Delhi: Pencraft International.

Mary Cappelli is a graduate and interdisciplinary scholar from USC, UCLA, and Loyola Law School, where she studied anthropology, theater film and television, law and literature. A former Lecturer at Emerson College, she currently researches the impact of globalization on indigenous populations in Africa and Central America. 